$\begin{array}{ccc}\text { Bentham OPen } & \text { The Open Petroleum Engineering } \\ \text { CrossMark } & \text { Content list available at: www.benthamopen.com/TOPEJ/ } \\ \text { DOI: } 10.2174 / 1874834101609010326 & \end{array}$

\title{
RETRACTION
}

\section{Retraction Notice: System Impact Relation and Mechanism of Safety Capacity in Petrochemical Base}

Jihong $\mathrm{Ye}^{1, *}$, Yibo Sun ${ }^{2}$ and Junshi Xiao ${ }^{2}$

${ }^{1}$ School of Petrochemical and Energy Engineering, Zhejiang Ocean University, Zhoushan, Zhejiang, 316022, China

${ }^{2}$ School of Engineering, China University of Geosciences, Wuhan, Hubei, 430074, China

\section{RETRACTION}

The Publisher and Editor have retracted this article [1] in accordance with good ethical practices. After thorough investigations we believe that the peer review process was compromised. The article was published online on 20-03-2015.

\section{REFERENCE}

[1] J. Ye, Y. Sun, and J. Xiao, "System impact relation and mechanism of safety capacity in petrochemical base", Open Pet. Eng. J., vol. 8, pp. 110-116, 2015.

This is an open access article licensed under the terms of the Creative Commons Attribution-Non-Commercial 4.0 International Public License (CC BY-NC 4.0) (https://creativecommons.org/licenses/by-nc/4.0/legalcode), which permits unrestricted, non-commercial use, distribution and reproduction in any medium, provided the work is properly cited.

* Address correspondence to this author at the Haida South Road, Zhoushan, Zhejiang, 316022, China; Tel: 0086+18368065661; E-mail: yjhong0106@163.com 